\title{
Scale insect species (Hemiptera: Coccomorpha) and their natural enemies, recorded on agricultural, ornamental and forest plant species in the wider area of Messenian Province (Peloponnese, Greece), 2000 - 2020
}

\author{
G.J. Stathas ${ }^{1, *}$, E.D. Kartsonas ${ }^{2}$, A.I. Darras ${ }^{2}$ and P.J. Skouras ${ }^{1}$
}

Summary The scale insects (Hemiptera: Coccomorpha) recorded on agricultural, ornamental and forest plant species in the wider area of Messenian Province (Peloponnese, Greece) during the years 2000 - 2020 are reviewed. Twenty species were recorded, which belong to four families: Diaspididae: Aonidiella aurantii (Maskell), Chrysomphalus aonidum (L.), Diaspis echinocacti (Bouché), Dynaspidiotus abieticola (Koroneos), D. abietis (Schrank), Lepidosaphes beckii (Newman), L. gloverii (Packard), Lineaspis striata (Newstead), Targionia vitis (Signoret); Coccidae: Ceroplastes rusci (L.), Eulecanium sericeum (Lindinger), Nemolecanium graniformis (Wünn), Parthenolecanium corni (Bouché), P. persicae (Fabricius), Physokermes hemicryphus (Dalman), P. inopinatus Danzig and Kozár, Protopulvinaria pyriformis (Cockerell); Pseudococcidae: Phenacoccus madeirensis Green, Planococcus vovae (Nasonov) and Kermesidae: Kermes echinatus Balachowsky. The biology, phenology and natural enemies in Messenia are discussed for fifteen of these scale species.

Additional keywords: Coccidae, Diaspididae, Kermecidae, Messenia, natural enemies, Pseudococcidae

\section{Introduction}

Information about the scale insects (Hemiptera: Coccomorpha) of Greece has been published in several articles of entomological journals, monographies and websites (Argyriou et al., 1976; Argyriou, 1983; DeBach, 1964; García Morales et al., 2016; Katsoyannos, 1996; Koroneos, 1934; Kozár et al., 1991; Milonas and Kozár, 2008; Paloukis, 1979; Pellizzari et al., 2011).

The present review contributes to this knowledge with a collective reference for twenty scale insect species found in Messenian Province, Peloponnese, Greece (Fig. 1) on agricultural, ornamental and forest plants species during the last twenty years.

\footnotetext{
1,2 Laboratory of Agricultural Entomology and Zoology and Laboratory of Floriculture, respectively, Department of Agriculture, School of Agriculture and Food, University of the Peloponnese, GR-241 00 Kalamata, Greece.

* Corresponding author: g.stathas@uop.gr
}

Messenia is a dynamic productive area in which economically important crops are cultivated, such as olives, citrus, vines, figs, potatoes, vegetables, etc. The knowledge of entomofauna in the wider region of Messenia and the record of the existing complex of the natural enemies of harmful insects, could be considered important to design plant protection programs in agriculture. The existence of dispersed small colonies of scale insects near the cultivated areas, could constitute a potential reservoir of parasitoids and predators for the control of prospective infestations of cultivations by these scale insect pests.

In fifteen out of the twenty recorded species, which were found in adequate population, biology, phenology and ecology data are available from studies conducted in the Laboratory of Biological Control of the Benaki Phytopathological Institute (years 2000 - 2003) and the Department of Agriculture of the University of the Peloponnese (former Technological Educational In- 


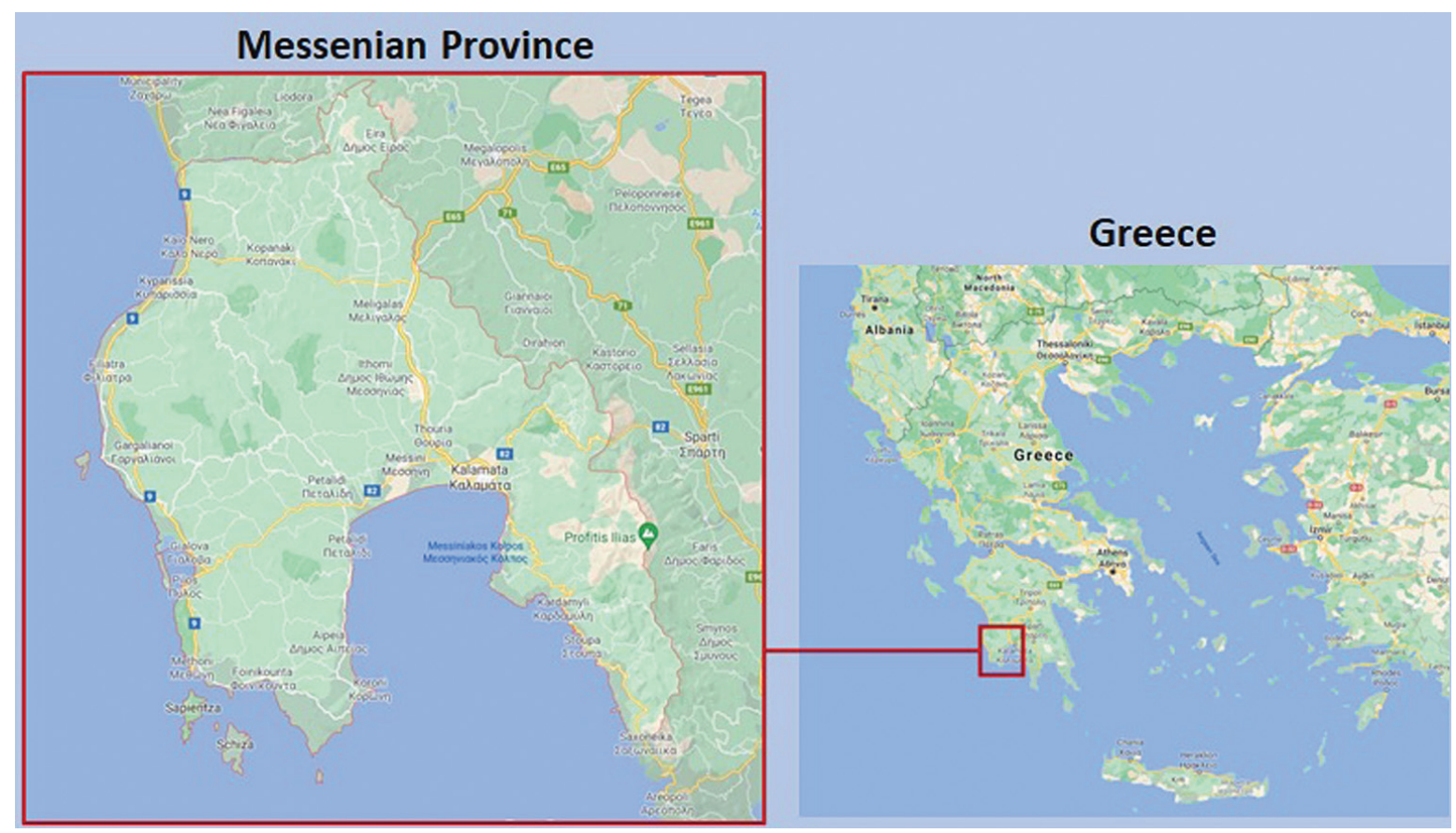

Figure 1. Messenian Province in Peloponnese, Southwestern Greece (Google map 1; Google map 2).

stitute of Peloponnese) (years 2004 - 2020). Information about the identification of the species, locations and materials and methods used for the biology/ecology studies is described in the articles of the cited bibliography. However, some information on materials and methods may be briefly presented when considered necessary.

Some scale insects recorded in this article were first records for Greece or first records on new host plant species of the scales, as it is referred in the cited references. Additionally, some natural enemies of the reviewed scale insects were first records for Greece or for Europe.

\section{DIASPIDIDAE}

\section{Aonidiella aurantii (Maskell)}

Aonidiella autantii is a cosmopolitan species distributed in 89 countries, infesting plants of 178 genera belonging to 84 families (García Morales et al., 2016).

It was recorded in Kalamata infesting Citrus sinensis (L.) Osbeck (Rutaceae) (Fig. 2). Field observations and laboratory examinations of infested leaves during March 2004 - April 2005 showed that $A$. aurantii completes three over-

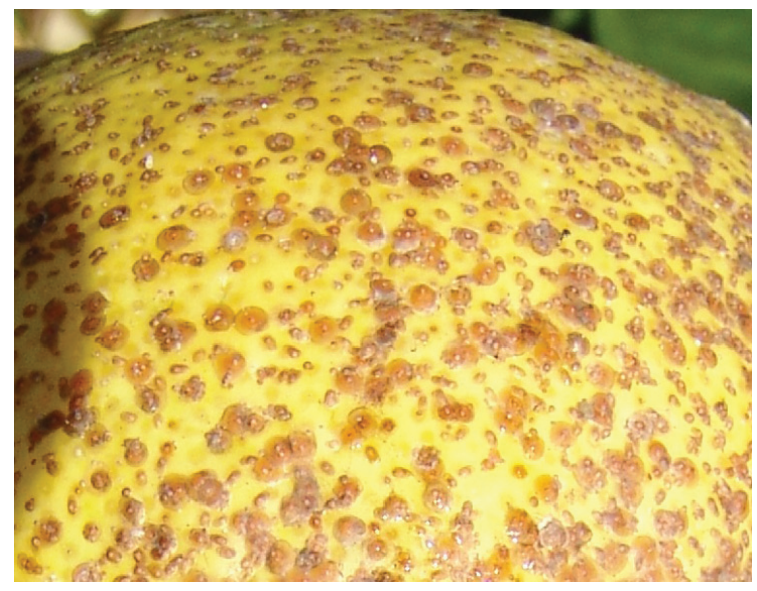

Figure 2. Orange fruit infested by Aonidiella aurantii in Kalamata, Greece (Photo by George Stathas).

lapping generations in Kalamata (Stathas et al., 2005). It overwintered under all developmental stages, but the majority of the population during November 2004 - March 2005 consisted of preovipositing and ovipositing female adults. During the rest months, scales of all developmental stages were recorded. Three picks of numbers of crawlers were observed: the first during the third ten days of April to the beginning of May, the second during the third ten days of June to the beginning of July and a third smaller increase observed from the end of August to the end of September. 
Natural enemies of $A$. aurantii found in Kalamata were the ectoparasite Aphytis chrysomphali (Mercet) (Aphelinidae) and the predator Chilocorus bipustulatus (L.) (Coleoptera: Coccinelidae). These natural enemies are reported also in other studies in Greece (Argyriou et al., 1976; Katsoyannos, 1996).

\section{Chrysomphalus aonidum (L.)}

Chrysomphalus aonidum originates from Asia but has become distributed in subtropical countries and worldwide in 87 countries, infesting plants of 181 genera belonging to 74 families (García Morales et al., 2016). It could be considered a serious threat for many European countries as it has been recorded to infest more and more several plants in Spain (Garcia Mari et al., 2000), Italy, (Pellizzari and Vacante, 2007), Hungary (Reiderne and Kozàr, 1994), France (Germain and Matile Ferrero, 2005) and the Netherlands (Jansen, 2004).

The first record of $C$. aonidum in Greece was reported by Koroneos (1934), as a pest of imported Citrus sp., which was not acclimatized in the country. Later, Argyriou and Mourikis (1981) reported that the scale was accidentally introduced in Greece during 1962-1965, but it had been under complete control. In April of the year 2000, C. aonidum was found on Dracaena sp. in Athens. The colony of this pest on Dracaena sp., was used to infest artificially pumpkins Cucurbita maxima Duchense (Cucurbitaceae) and potato tubes Solanum tuberosum L. (Solanaceae) in the laboratory and was the first record of the scale on plant species of these families (Stathas et al., 2002).

In January 2007, C. aonidum was found on heavily infested fruits of Citrus limon and C. sinensis (L.) (Rutaceae) and leaves of Ficus benjamina L. (Moraceae) and Ligustrum japonicum Thunb. (Oleaceae) in Kalamata (Stathas and Kozár, 2008) and later in the same year on Nerium oleander L. (Apocynaceae) (Fig. 3). Infestation on F. benjamina (Moraceae) was the first record of the scale on this new host. It is a biparental and oviparous species. The population of the scale found on all the host plants in Kalamata from January to April 2007 consisted main- ly of young female adults.

Regarding the natural enemies of the scale, the biology of the predator Rhyzobius lophanthae Blaisdell (Coleoptera: Coccinellidae) was studied under controlled conditions in the laboratory (Stathas et al., 2002).

\section{Diaspis echinocacti (Bouché)}

Diaspis echinocacti (Bouché) is recorded in 74 countries of the world, infesting 58 plant species belonging to the family Cactaceae and 9 plant species belonging to other families (García Morales et al., 2016).

In Kalamata it was recorded on Opuntia ficus-indica (L.) Mill. (Cactaceae) (Fig. 4) and examination on its populations were made in nature and in laboratory, from February to June 2009 (Japoshvili et al., 2010). Diaspis echinocacti was found to be biparental and oviparous. The populations of the scale in February 2009 consisted of all development stages except crawlers, which hatched during the first half of April. Until June, all development stages of the scale were present on O. ficus-indica.

Natural enemies of $D$. echinocacti recorded in Kalamata include the ectoparasitoid Aphytis debachi Azim (Hymenoptera: Aphelinidae), the endoparasitoid Plagiomerus diaspidis Crawford (Hymenoptera: Encyrtidae), the predator Cybocephalus fodori Endrödy-Youga (Coleoptera: Cybocephalidae) and small numbers of individuals of an unidentified predatory mite of the family Bdellidae (Prostigmata) (Japoshvili et al., 2010). Aphytis debachi parasitized second instar nymphs and preovipositing females of the scale. Its parasitization rate reached 9.3\% in March 2009. Both sexes of the parasitoid were recorded, which support the biparental status of the species (Japoshvili et al., 2010) whereas only female adults were obtained in Hong Kong (Rosen and DeBach, 1979). Plagiomerus diaspidis parasitized second instar nymphs. Its parasitization rate reached $86 \%$ in March 2009. The endoparasite P. diaspidis has also been reported as a natural enemy of $D$. echinocacti in other studies (Gordh and Lacey, 1976; Panis and Pinet, 1999). The predator $C$. fodori was found to be very ac- 

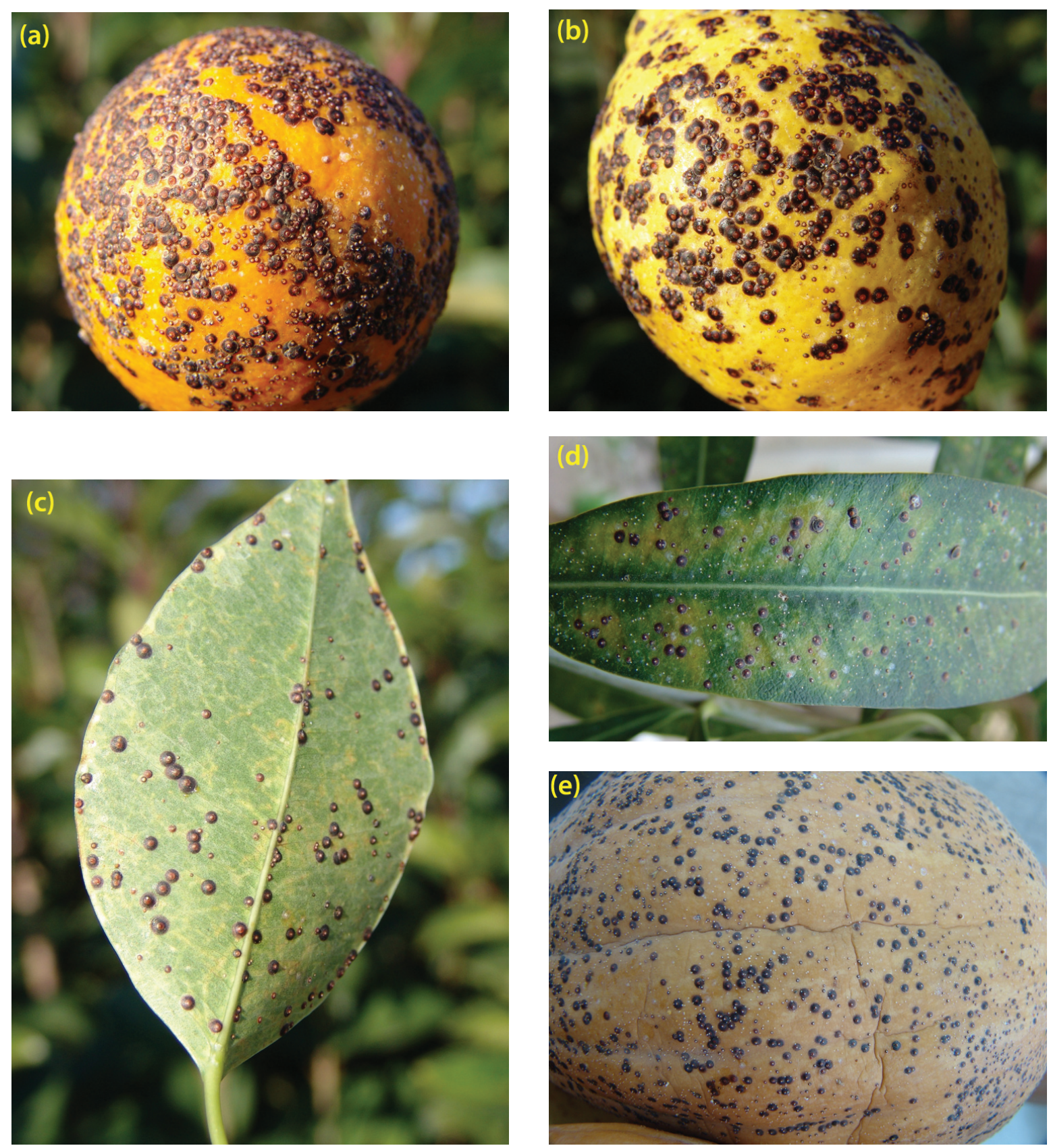

Figure 3. Infestation of Chrysomphalus aonidum on several host plants in Kalamata, Greece: (a): Citrus sinensis, (b): Citrus limon, (c): Ficus benjamina, (d): Nerium oleander, (e): rearing of the scale on Cucurbita maxima in laboratory for experimental reasons (Photo by George Stathas).

tive as the predated scales reached $90 \%$ of the population in June 2009 in Kalamata. This is the first record of $A$. debachi in Europe and the first record of $P$. diaspidilis in Greece (Japoshvili et al., 2010).

\section{Dynaspidiotus abieticola (Koroneos)}

Dynaspidiotus abieticola is a Paleartctic species, recorded in Greece, Iran, Lebanon and Turkey, on the following plant species of the family Pinaceae: Abies bornmuelleriana, A. cephalonica, A. concolor, Cedrus libani and Picea pungens (García Morales et al., 2016). The first record of the scale in Greece was made by Koroneos (1934) on A. cephalonica, in the area of Ano Lekhonia and in the surrounding region of mount Pelion (Thessaly).

In the area of Messenia, it was recorded on Taygetus mountain at an altitude of $760 \mathrm{~m}$ (Fig. 5). The study of phenology of the 
scale was made by examinations of branches of the infested trees in the laboratory from February 2013 to January 2014 (Stathas, 2015). It was recorded as an oviparous biparental species which completed one generation per year. It was settled on fir trees causing chlorosis (Fig. 5). On heavily infested fir trees, needles got dry. It overwintered as a mated adult female from the beginning of October to the end of April. Egg-laying and hatching of crawlers occurred from early May to the end of June. Settled first instar nymphs were present from early June until early September. Second instar nymphs occurred from the first days of August until late September, the male nymphs in September and the first adult females at the beginning of October.

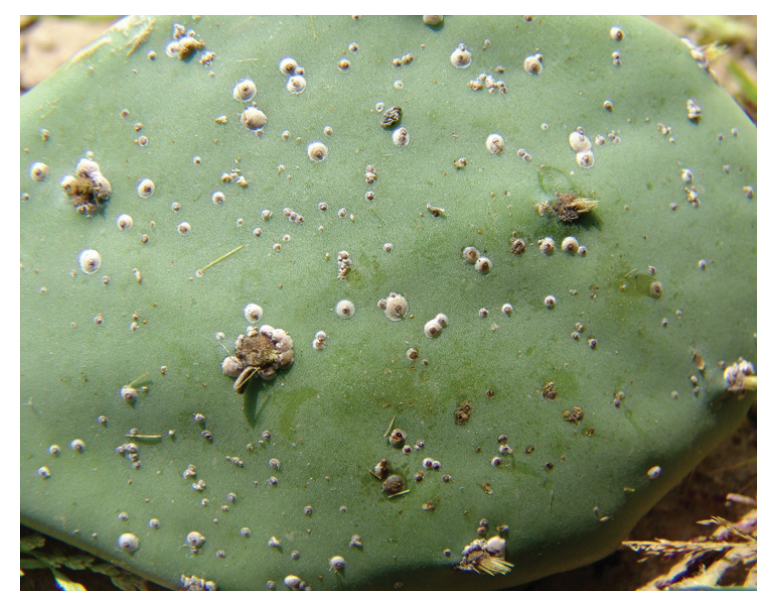

Figure 4. Diaspis echinocacti on Opuntia ficus-indica in Kalamata, Greece (Photo by George Stathas).

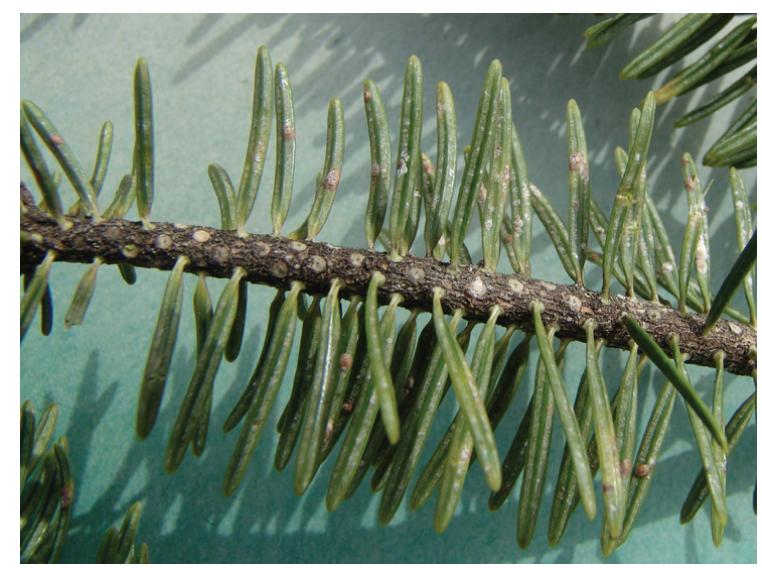

Figure 5. Dynaspidiotus abieticola on Abies cephalonica on Taygetus mountain, Messenia, Greece (Photo by George Stathas).

\section{Dynaspidiotus abietis (Schrank)}

Dynaspidiotus abietis is a species of Nearctic and Palaearctic region, recorded in 26 countries, infesting plants of the families Cupressaceae, Pinaceae, Rosaceae and Sapindaceae (García Morales et al., 2016).

Its first record for Greece was made by Koroneos (1934), who referred to the scale as Aspidiotus abietis (Schr.) Loew, on A. cephalonica on the mountains Parnitha (Attica) and Oeta (central Greece).

In Messenia, D. abietis was recorded on A. cephalonica on northwestern part of the mountain Taygetus (near to the County Dyrachi). Its morphology, biology, phenology and natural enemies were studied during June 2004 - August 2006, on infested fir trees and on samples of infested branches examined in the laboratory (Stathas, 2008). The scale was found to infest only needles of the fir trees, in low infestation levels (Fig. 6). It is biparental and oviparous; it developed one generation per year and it overwintered as mated pre-ovipositing female adult. Ovi-

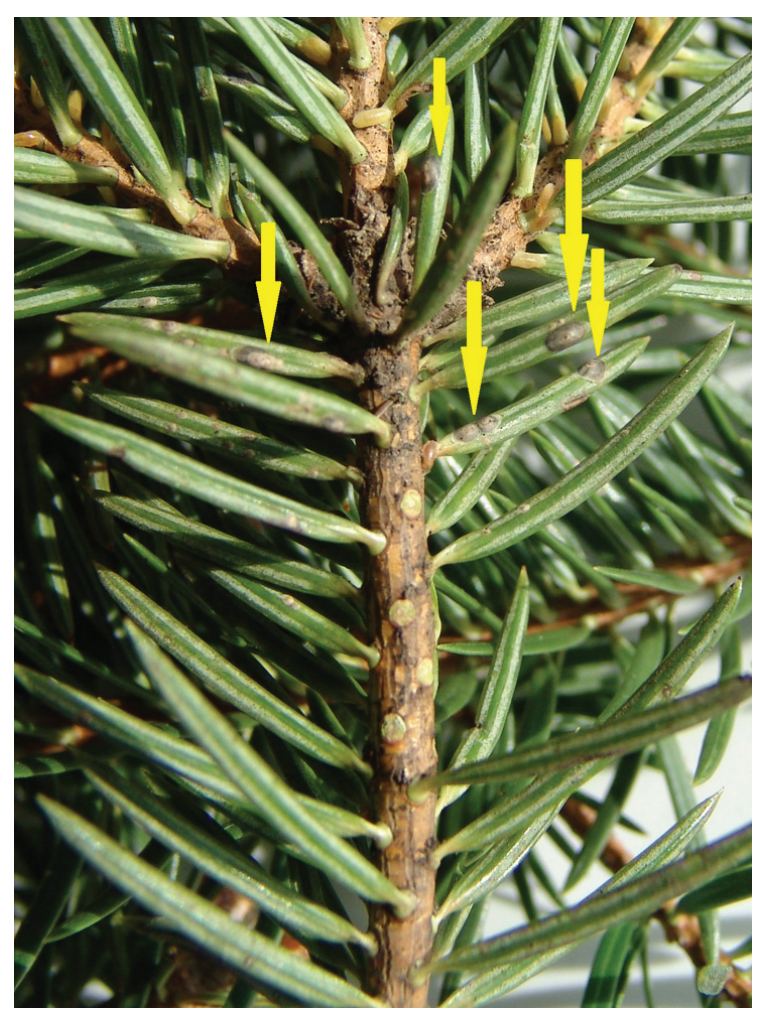

Figure 6. Female adults of Dynaspidiotus abietis settled on needles of Abies cephalonica on Taygetus mountain, Messenia, Greece (Photo by George Stathas). 
positing females were recorded from the second week of May to the beginning of July. Crawlers appeared from the end of May to the beginning of July. Settled first instar nymphs were recorded during July and second instar nymphs from August to October.

Predated individuals of the scale on the infested trees were attributed to the activity of the larvae and adults of the predator Chilocorus bipustulatus (L.) (Coleoptera: Coccinellidae), which were recorded between the months May to August (Stathas, 2008). Activity of $C$. bipustulatus against $D$. abietis is also reported in other European countries by Kozstarab and Kozár (1988).

\section{Lepidosaphes beckii (Newman)}

Lepidosaphes beckii is a widely distributed, cosmopolitan, tropical and subtropical species. It infests citrus in all northern Mediterranean countries and is especially harmful in littoral areas (Katsoyannos, 1996). It is distributed to 120 countries and its host plant species belong to 60 genera of 42 families, but most of its hosts belong to the family Rutaceae (García Morales et al., 2016). The presence of $L$. beckii in Greece was reported by Hall (1922), DeBach (1964), Argyriou (1976) and Katsoyannos (1996).

The ecology of the scale was studied on infested Citrus sinensis var. navelina in Kalamata during 2009-2011 (Fig. 7) (Stathas et al., 2015a). Its phenology was studied on samples of infested leaves, which were transferred in the laboratory. The numbers of caught males of $L$. beckii, the parasitoids and predators of the scale were monitored by yellow sticky traps on the infested trees. Lepidosaphes beckii mainly infested the leaves and fruits and to a lesser extent the shoots and stems. The fluctuations of the population of crawlers were recorded using sticky transparent band traps placed on shoots of the infested trees. All developmental stages of the scale were observed during all the period of the study. Three peaks of crawlers were recorded in June, August and October in both years of the study.

The natural enemies of $L$. beckii recorded in Kalamata were the parasitoids Aphytis lepidosaphes Compère and Encarsia sp. (Hymenoptera: Aphelinidae) which reached a parasitization rate $32 \%$, and the predators Chilocorus bipustulatus (L.) and Rhyzobius lophanthae Blaisdell (Coleoptera: Coccinellidae) (Stathas et al., 2015a). García Morales et al. (2016) reported that the recorded natural enemies of $L$. beckii belong to 35 genera of 17 insect families, in which the above-mentioned natural enemies of the scale recorded in Kalamata are included.

\section{Lepidosaphes gloverii (Packard)}

Lepidosaphes gloverii is distributed to 81 countries of Central and North America, Asia and Europe, recorded on host plants of 40 genera in 28 families. Its main host is citrus (García Morales et al., 2016).

In Greece, it was recorded in southern Peloponnese in the area Gastouni on Citrus sinensis var. navelina (Stathas, 2004a). Its biology, phenology and ecology were studied during June 2001 - August 2003, with examination of the infested trees and on samples of infested leaves in the laboratory. The scale infests mainly the upper leave surface and the fruits and less the lower leaf surface and the shoots of the trees. Although all developmental stages were recorded during the winter period, the scale was found to overwinter mainly as preovipositing and ovipositing female adult. It developed 3 overlapping generations per year. Three peaks of the population of crawlers were recorded in June, August and October. The number

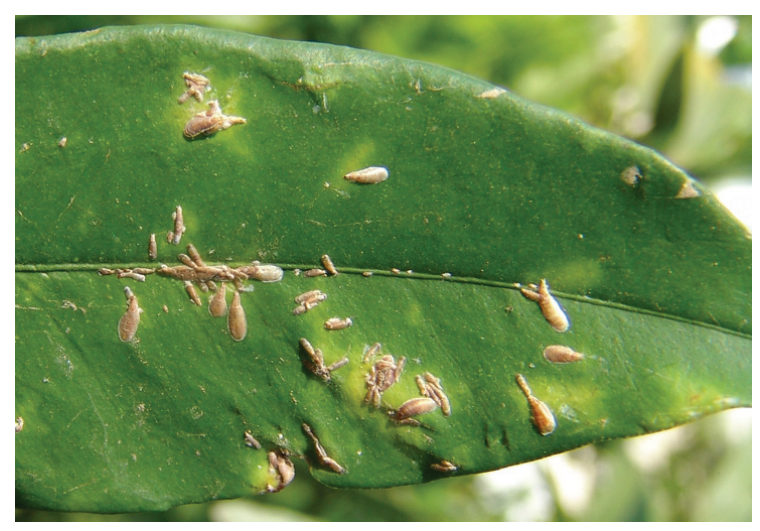

Figure 7. Male and female nymphs and adults of Lepidosaphes beckii settled on upper surface of orange tree leaf in Kalamata, Greece (Photo by George Stathas). 
of eggs recorded under the ovipositing female adults in June, ranged between 32 and 57 eggs, with a mean number of 37.7 eggs per female.

Concerning its control, the combination of mineral oil applications in September 2001, February and September 2002 with mass releasing of adults of the predators Chilocorus bipustulatus (L.) and Rhyzobius lophanthae Blaisdell (Coleoptera: Coccinellidae) in July 2002, reduced significantly the infestation density of the scale (Stathas, 2004a). The coccinellid predators $C$. bipustulatus and $R$. lophnathae are also cited as natural enemies of $L$. gloverii in other studies (Belguendouz et al., 2017; Herting and Simmonds, 1972).

\section{Lineaspis striata (Newstead)}

Lineaspis striata is recorded in 16 countries infesting plants of 9 genera belonging to the families Cupressaceae, Iridaceae, Santalaceae and Taxaceae (García Morales et al., 2016).

It was recorded and described in Greece by Koroneos (1934) as Chionaspis striata Newstead found on the species of the family Cupresaceae: Thuja orientalis L. in Volos, Cupresus sempervirens L. in Peloponnese, on Juniperus oxycedrus L. in Pelion Mountain (Tsangarada and Milies), on Juniperus macrocarpa (Sibth. and Sm.) in Attica (Voula) and on Juniperus phoemicae L. in Attica (Vouliagmeni). It is also recorded in Crete by Panis (1981) and by Pellizzari et al. (2011) on C. sempervirens in Agios Nikolaos and on Cupresus sp. in Heraklion. In Messenia, L. striata was found on Juniperus oxycedrus L. (Cupressaceae) on Taygetus Mountain in January 2007 (Stathas et al., 2011).

The phenology and the natural enemies of the scale were studied by Katsoyannos (1993) on different species of the family Cupresaceae during the years 1991-1992 in Attica. As it is referred in the above study, the scale is oviparous biparental species. It developed three generations per year and it overwintered as pre-ovipositing female adult. The average fecundity was $50 \pm 12$ eggs per female. The endoparasitoid Physcus testaceus Masi (Hymenoptera: Aphelinidae) was found to parasitize female adults of $L$. striata and the parasitism rate reached $44.8 \%$ in May 1991. Parasitism of a single female adult $L$. striata by an ectoparasite Aphytis sp. was recorded in April 1991 (Katsoyannos, 1993).

\section{Pseudaulacaspis pentagona (Targioni Tozzetti)}

Pseudaulacaspis pentagona is distributed in 113 countries, was recorded on host plants of 251 genera, belonging to $89 \mathrm{fam}$ ilies (García Morales et al., 2016). Its presence in Greece is referred by Balachowsky (1954), Paloukis (1967), Argyriou et al. (1976). Its phenology and ecology have been studied in the past in northern Greece (Paloukis and Mentzelos, 1971; Kyparissoudas, 1992).

In southern Greece P. pentagona was recorded in Kalamata infesting Actinidia deliciosa (Actinidiaceae), Prunus persica (Rosaceae) Morus alba (Moraceae) (Fig. 8) (Stathas et al., 2020). In Kalamata the biology and ecology of $P$. pentagona on M. alba was studied during the years 2016 - 2018. It is a biparental and oviparous species. It overwintered as mated female adult. The fecundity of females on September 2017 fluctuated between 97 to 133 eggs, with a mean $118.5 \pm$ 25.7 eggs per female. The scale completed 3 generations per year. Three peaks of crawlers were recorded in April, July and September. The parasitism rate by an unidentified ectoparasite reached 18 and $21 \%$ in 2016 and 2017, respectively. The main natural enemies of the scale were the coccinellid predators Chilocorus bipustulatus and Rhyzobius lophanthae (Stathas et al., 2020). These predators are referred as natural enemies of $P$. pentagona in other countries (García Mo-

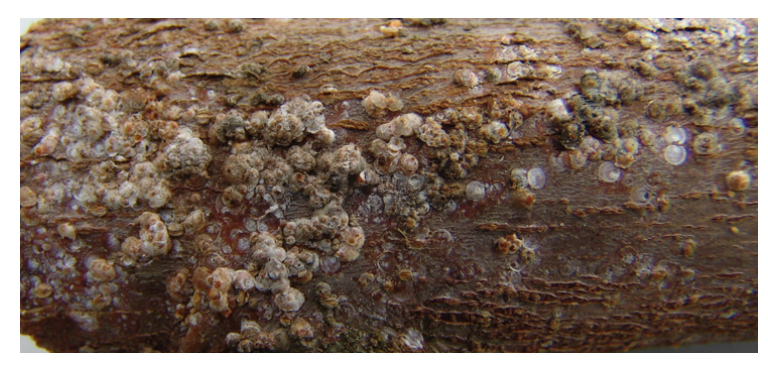

Figure 8. Pseudaulacaspis pentagona on branch of Morus alba in Kalamata, Greece (Photo by George Stathas). 
rales et al., 2016) and in northern Greece (Argyriou et al., 1976).

\section{Targionia vitis (Signoret)}

Targionia vitis is recorded in 25 countries, infesting plants of 9 genera in 6 families, but most of its host plants belong to the family Fagaceae (García Morales et al., 2016). Its presence in Greece was recorded by Koroneos (1934) on Arbutus unedo (L.) (Ericaceae), Quercus sp. and Q. coccifera L. (Fagaceae) and Platanus orientalis L. (Platanaceae).

Targionia vitis was recorded and studied in Messenia on Vitis vinifera L. (Vitaceae) in a vineyard containing the varieties Black Currents (black raisin), Rodites and Fraoula (Stathas and Kontodimas, 2001). It was recorded as a biparental, viviparous univoltine species, which overwinters as mated female adult. The crawlers hatched in mid - May, while the first and second instar nymphs appeared in June and developed to male and female nymphs by mid-July. Male adults were observed from mid-July until the end of August while by the beginning of September, the whole population of the scale consisted of mated female adults. The fecundity of $T$. vitis ranged between 82 and 105 eggs, with an average of $94.9 \pm 9.37$ eggs per female. The natural enemies of $T$. vitis, which were recorded in Messenia, included the ectorarasite Aphytis abnormis (Howard) (Hymenoptera Aphelinidae), an unidentified endoparasite and the predator Cybocephalus fodori Entrödy-Younga (Coleoptera: Nitidulidae). The activity of the above natural enemies could not reduce the population density of the scale on the infested grapes (Stathas and Kontodimas, 2001).

\section{COCCIDAE}

\section{Ceroplastes rusci (L.)}

Ceroplastes rusci is distributed to 58 countries, infesting plants of 79 genera belonging to 48 families (García Morales et al., 2016). In Greece it is referred by Argriou (1983) as widely distributed scale insect causing serious damage, especially in southern areas of the country, on Ficus carica L. (Moraceae) in Attica and Messenia and on citrus in Aegean islands. Kozár et al. (1991) referred C. russci in Greece on Albizia sp. (Fabaceae) in Athens, on Pittosporum sp. (Pittosporaceae) in Iraklion, on Nerium oleander L. (Apocynaceae) in Knossos and on Osyris alba L. (Santalaceae) in island Hydra. Ceroplastes rusci was reported to develop two generations per year on fig trees in Greece (Argyriou and Santorini, 1980).

In Messenia, C. rusci is widely spread on fig trees (Fig. 9). Pellizzari et al. (2010) recorded $C$. rusci on $F$. carica in a fig cultivation area near Kalamata (province Aristomenes). Description of immature females from this population provided an identification key of the different instars of the scale which is a useful tool for the determination of the appropriate period for effective chemical control applications in fig cultivation.

\section{Eulecanium sericeum (Lindinger)}

Eulecanium sericeum is distributed in 14 European countries, infesting 6 species of genus Alba (Pinaceae). In Greece, it has been recorded on A. cephalonica and A. borisii-regis Mattf. (Argyriou, 1983; Santas,1983;1988). Santas (1983) reported that E. sericeum appeared in patches on the Abies trees, although sometimes a whole tree may be infested. In Messenia, E. sericeum was found on A. cephalonica on Taygetus Mountain in June 2005 and in June 2007 in small colonies

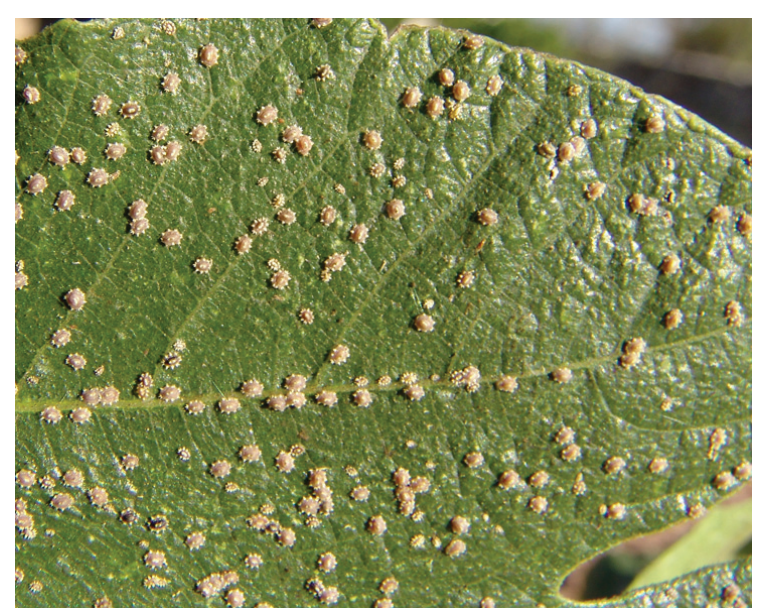

Figure 9. Immature stages of Ceroplastes rusci on fig tree leaf (Photo by George Stathas). 
(Stathas et al., 2011). According to Hadzibejli (1967) E. sericeum develops one generation per year in Georgia.

\section{Nemolecanium graniformis (Wünn)}

Nemolecanium graniformis is recorded only in Europe, in Czech Republic, France, Germany, Greece, Italy and Poland, infesting Abies alba, Abies cephalonica and Abies nebrodensis (Pinaceae) (García Morales et al., 2016). It was first recorded in Greece in August 1996 on A. cephalonica in the area Thracomacedones (Attica) (Stathas, 1997).

Its phenology and natural enemies were studied on Parnis Mountain (Attica) during 1998-1999, where the scale was found to be univoltine, oviparous and overwintered as second instar nymph. The average fecundity of the scale on Parnis Mountain was counted to 188.4 eggs per female adult (Stathas, 2001). In Messenia N. graniformis, it was found on A. cephalonica on Taygetus Mountain where it was studied from December 2005 to November 2007 (Fig. 10) (Stathas et al., 2011). It is oviparous and biparental species and it completed one genera-
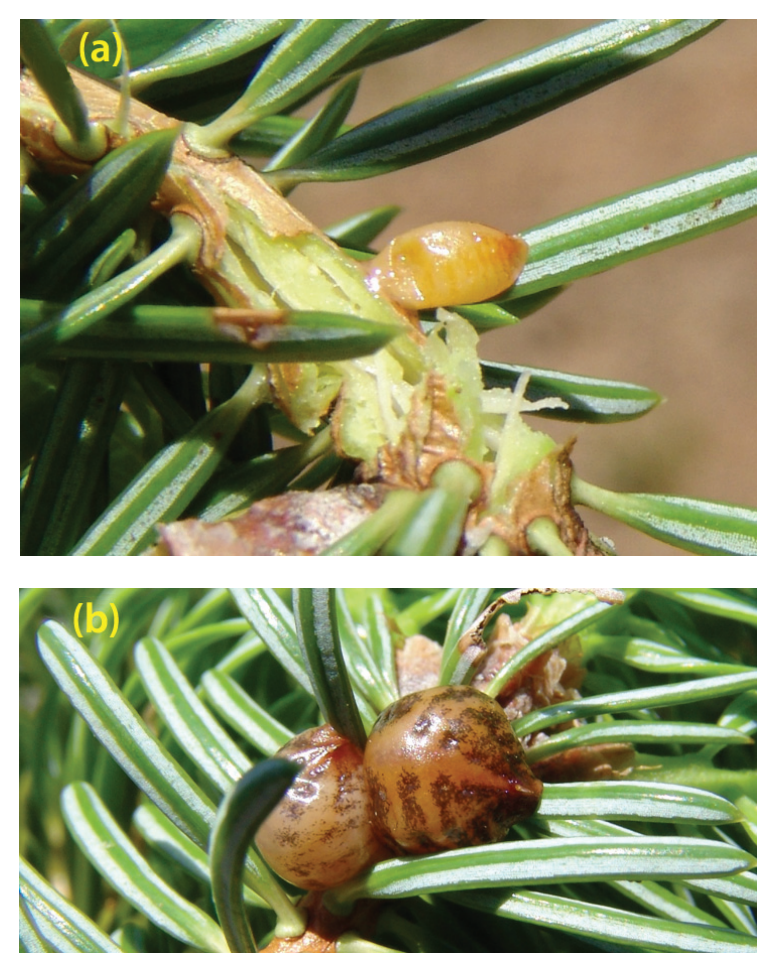

Figure 10. Nemolecanium graniformis on Abies cephalonica: Second instar nymph (a) and female adults (b) on Taygetus mountain, Messenia, Greece (Photo by George Stathas). tion per year and overwintered as second instar nymphs. Regarding its natural enemies in Messenia, female adults of the scale were found parasitized by unidentified endoparasitic larvae on Taygetus Mountain, in June and November 2006. Moreover, the predators E. quadripustulatus and C. bipustulatus were found in the colonies of the scale on the infested fir trees (Stathas et al., 2011). In other studies in Greece, the aphelinid parasitoids Coccophagus lycimnia (Walker), Coccophagus sp. Westwood and the encyrtid Aphycoides sp. Mercet, as well as the predators Exochomus quadripustulatus L. and C. bipustulatus were recorded on Parnis Mountain, County of Attica (Stathas, 2001).

\section{Parthenolecanium corni (Bouché)}

Parthenolecanium corni is distributed in 73 countries, infesting 109 plant species belonging to 48 families (García Morales et al., 2016).

In Greece it is referred by Argyriou (1983) on Prunus persica L. (Rosaceae) and by Santas (1985) on P. persica, Prunus armeniaca, Crataegus spp. (Rosaceae) and Corylus avellana L. (Betulaceae) close to Grevena (Northwestern Greece). Its distribution in Greece is not well known, but it has been found in Central and Northern Greece. The adults excrete honeydew which is exploited by honeybees. Parthenolecanium corni had one generation per year on C. avellana. It overwintered as second instar nymph, the adults appeared early in April and the crawlers in the middle of June. The second instar nymphs appeared in mid-July and by the end of October all the scale population was in this stage. The fecundity of the scale fluctuated between 700 and 1100 eggs per female (Santas, 1985).

Natural enemies of $P$. corni in Greece included the parasitoids Coccophagus lycimnia (Wlk.) (Hymenoptera: Aphelinidae), Metaphycus insidiosus (Merc.) (Hymenoptera: Encyrtidae) and the predators Scutellista cyanea Motsch. (Hymenoptera: Pteromalidae), Leucopis alticeps Czerny (Diptera: Chamaemyiidae), Eubletnma scitula (Ramb.) (Lepidoptera: Noctuidae), Chrysoperla carnea (Stephens) (Neuroptera: Chrysopidae) and 
Chilocorus hipustulatus (L.) (Coleoptera: Coccinellidae) (Santas, 1985). The hyperparasites Pachyneuron concolor (Forst) (Hymenoptera: Pteromalidae) and Marietta picta (André) (Hymenoptera: Aphelinidae) were also recorded (Santas, 1985).

In Messenia, P. corni was found in the area Asprochoma close to Kalamata on Morus alba in July 2005. The population of the scale consisted of ovipositing females. Female adults of the scale were deposited to the collection of the Hungarian Academy of Sciences. Superparasitism of female adults $P$. corni by an unidentified parasitoid species was also observed in the above infestation (Fig. 11) (Stathas and Kartsonas, unpublished data).

\section{Parthenolecanium persicae (Fabricius)}

Parthenolecanium persicae is distributed in 59 countries on several host plants of 54 genera, belonging to 33 families. Most of its hosts belong to the families Fabaceae and Rosaceae (García Morales et al., 2016). In Greece, it was recorded by Kozár (1985) on Morus sp. in northern Greece and on Viburnum tinus (L.) (Adoxaceae) in Athens (Stathas, 2004b).

In Messenia, P. persicae was found on Vitis vinifera L. (Vitaceae) in the province Arfara in October 2000 (Stathas et al., 2003; Stathas, 2004b). In studies of $P$. persicae in vineyards CV. Rodites during the years 20012002 it was found to be parthenogenic, oviposoting, univoltine species. Although $P$. persicae appears to be largely parthenogenic, two male adults of $P$. persicae were collected from vineyards in the Hunter Valley (Australia) during early September (Rakimov et al., 2013). The scale overwintered as a second instar nymph. Female adults appeared in April and oviposition took place from early May to late June. Crawlers hatched in May and during the rest of the summer period the population consisted of first and second instar nymphs. From late September until the following spring the population consisted of second instar nymphs. Regarding natural enemies of $P$. persicae, two parasitoids were recorded, Metaphycus sp. (Hymenoptera: Encyrtidae), which parasitized the scale up to $34.5 \%$, and the predator Chilocorus bipustulatus (Stathas et al., 2003).

\section{Physokermes hemicryphus (Dalman)}

Physokermes hemicryphus is distributed in 28 countries on conifers of the families Pinaceae (on species of genera Abies, Picea
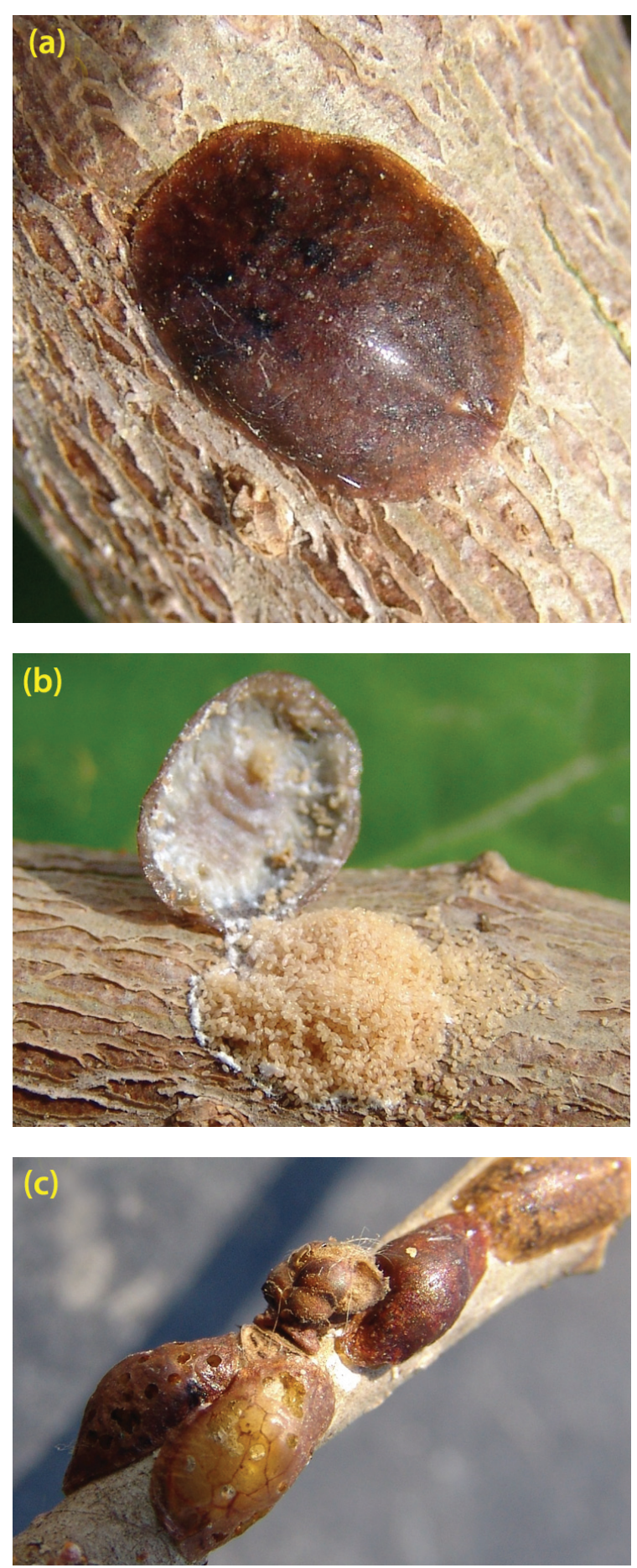

Figure 11. Parthenolecanium corni on Morus alba. Dorsal (a) and ventral (b) view of ovipositing female adults, parasitized females (c) in Kalamata, Greece (Photo by George Stathas). 
and Tsuga) and Cupressaceae (on Juniperus sp.) (García Morales et al., 2016).

In central Greece it has been recorded on Abies cephalonica and A. borisii regis, where the honeydew excretions of the scale is used in beekeeping as a main source for honey production in the country (Argyriou, 1983; Santas, 1988; Gounari et al., 2004). In Messenia, $P$. hemicryphus was recorded on Taygetus Mountain infesting $A$. cephalonica (Fig. 12). The biology and ecology of the scale was studied in this area during the years 2004 2006 (Stathas et al., 2011). It is an oviparous biparental and univoltine species, infesting the nodes of the annual growth of the trees. It overwintered as second instar nymph. Young female adults secrete honeydew from the middle of May until the beginning of July (Fig. 12). On Taygetus Mountain, ovipositing females laid 70-280 eggs in July 2006 and the mean fecundity was $193.9 \pm 44.6$ eggs per female. The crawlers appeared from the end of August until the middle of September.

Concerning the natural enemies on Taygetus Mountain, the parasitoid Pseudorhopus testaceus (Ratzeburg) (Hymenoptera: Encyrtidae) was found to parasitize female adults of $P$. hemicryphus. Percentage parasitism was $24 \%$ in July 2005 and $47.8 \%$ in July 2006 with 1-4 or more parasitoid adults emerging per parasitized female adults. The predators Chilocorus bipustulatus (L.), Exochomus quadripustulatus (L.) and Scymnus sp. (Coleoptera: Coccinallidae). Exochomus quadripustulatus and Scymnus sp. are also reported as predators of the scale in western and central Greece (Santas, 1988). The role of E. quadripustulatus against other coc-

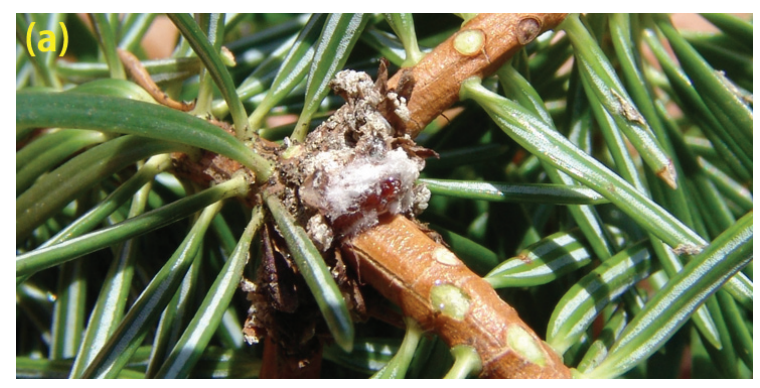

cids in Greece such as Saissetia oleae Olivier has been studied by Katsoyannos (1976).

\section{Physokermes inopinatus Danzig and Kozár}

Physokermes inopinatus is recorded in Austria, Hungary, Greece, Romania, Sweden and Ukraine. Its hosts are species of genus Abies and Picea (Pinaceae). It causes damage to the host trees by its feeding on the sap from the needles as well by its honeydew secretions, on which sooty mold is created (García Morales et al., 2016).

The first record of $P$. inopinatus in Greece was on Abies cephalonica on Taygetus Mountain, in Messenia (Stathas and Kozár, 2010). The phenology of the scale was studied on infested fir trees in this area from July 2006 to June 2008. The scale settles on the base of young shoots and needles. It is oviparous and biparental. It completed one generation per year and overwintered as second instar nymphs. Pre-ovipositing females appeared during May and June. Eggs were laid from mid-June to early August. Hatching of crawlers occurred during July and August. Larvae and adults of $C$. bipustulatus were observed on colonies (Stathas and Kozár, 2010). The coccinellid predator C. bipustulatus is included among the natural enemies of $P$. inopinatus by Kosztarab and Kozár (1988).

\section{Protopulvinaria pyriformis (Cockerell)}

Protopulvinaria pyriformis is a serious pest of fruit trees and ornamentals in several tropical and subtropical countries, totally recorded in 42 countries, infesting plants of 60 genera, belonging to 36 families (García

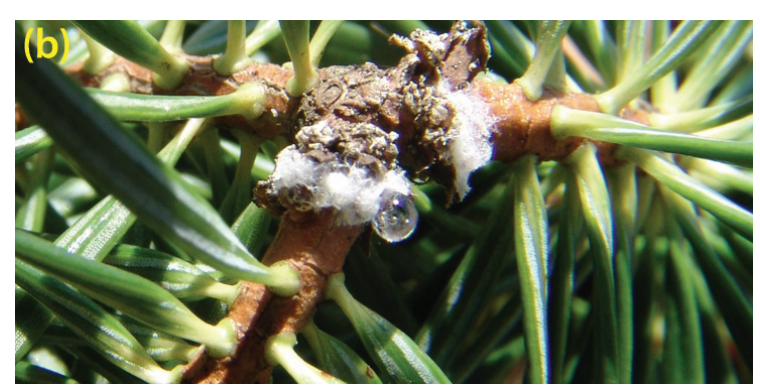

Figure 12. Young female adults of Physokermes hemicryphus on nodes of Abies cephalonica partially covered by white waxy filaments (a) and totally covered by filaments and honeydew excretion (b) on Taygetus mountain, Messenia, Greece (Photo by George Stathas). 
Morales et al., 2016).

In Greece, it was recorded for the first time on Laurus nobilis L. (Lauraceae) in Kalamata (Fig. 13), Messenia, in 2003 (Ben-Dov, et al., 2003). Later, P. pyriformis was found on more host plants in Messenia. In June 2007, it was found on Hedera helix L. (Araliaceae) at the area of Almyros, Messenia and in May 2008 on Citrus aurantium L. (Rutaceae) in the city of Kalamata (Fig. 13). On both of the above host plants, P. pyriformis was found to settle mainly on the lower leaf surface (Stathas et al., 2008).

The phenology, biology and natural enemies of the scale were studied in Messenia during the years 2003 - 2005 (Stathas et al., 2009). It settles mainly on the lower leaf surface producing increased amounts of honeydew throughout the year. It is parthenogenetic and oviparous developing several overlapping generations per year. It overwintered under all developmental stages (egg, first and second instar nymph, adult).
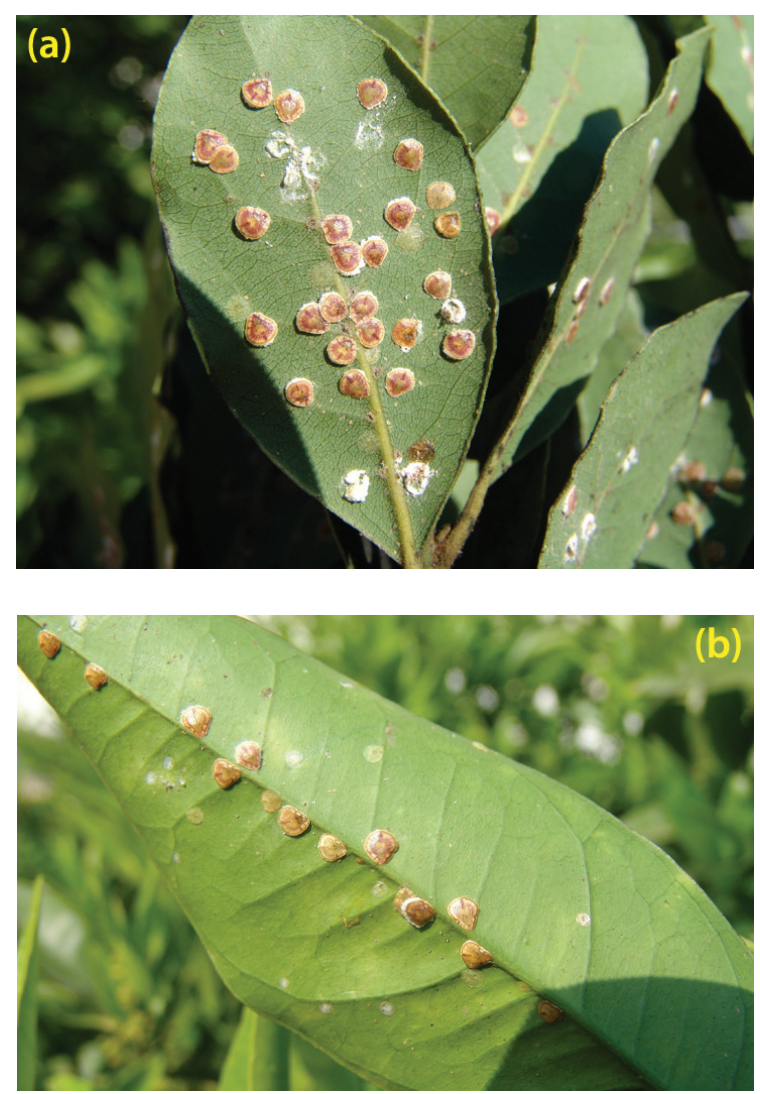

Figure 13. Protopulvinaria pyriformis on Laurus nobilis (a) and on Citrus aurantium (b) in Kalamata, Greece (Photo by George Stathas).
The life cycle was estimated to last in nature about 52 days during winter and 29-33 days during summer. The main natural enemy of the scale was the parasitoid Metaphycus helvolus (Compere) Hymenoptera: Encyrtidae). The parasitism rate reached $31.2 \%$ while encapsulation of the parasitoid eggs occurred in up to $23 \%$ of the adult scales. The number of the encapsulated eggs ranged from 1 to 5 eggs per scale individual. The coccinellid predator C. bipustulatus was also recorded as a natural enemy of the scale in Kalamata.

\section{PSEUDOCOCCIDAE}

\section{Phenacoccus madeirensis Green}

Phenacoccus madeirensis is widely spread in 83 countries, recorded on host plants belonging to 150 genera of 54 plant families (García Morales et al., 2016).

In Greece it was recorded by Papadopoulou and Chryssohoides (2012) in June 2010 in the regions of Thessaloniki, Xanthi and Kavala (Northern Greece) on Onicum basilicum L. (Lamiaceae) and by Szita (et al., 2017) in 2014 in the island Kefalonia (Western Greece) on Campanula sp.

In Messenia, P. madeirensis was found in Kalamata in May 2014 on Aloysia citriodora Palau (Verbenaceae) and on July of the same year on Osteospermum jucundum (Phillips) (Asteraceae) (Fig. 14). Osteospermum jucundum recorded for the first time as host plant

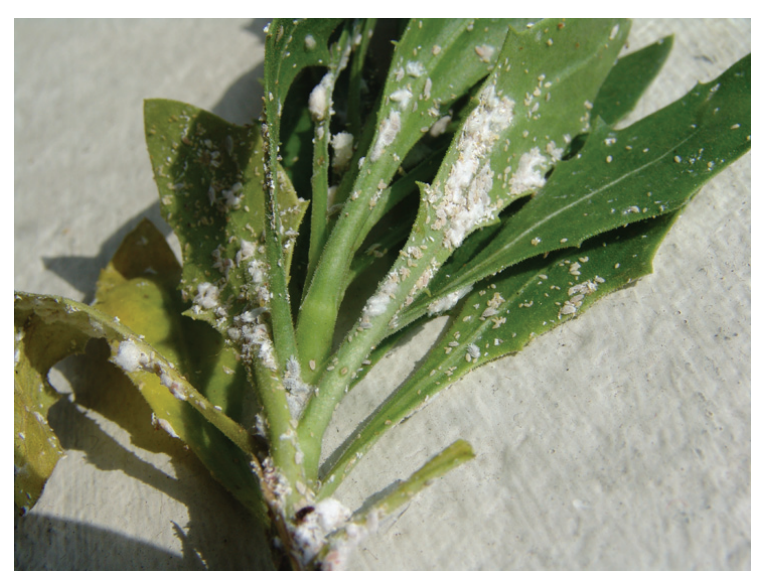

Figure 14. Infestation of Phenacoccus madeirensis on Osteospermum jucundum in Kalamata, Greece (Photo by George Stathas). 
of $P$. madeirensis (Stathas et al., 2015b).

As far as the phenology is concerned, $P$. madeirensis completed 5-6 generations per year in Sicily; it overwintered mainly as first and second instar nymphs however, female adults were also found (Sinacori, 1995).

\section{Planococcus vovae (Nasonov)}

Planococcus vovae is distributed to 38 countries, infesting plants of the families Araceae (genus: Anthurium), Cupressaceae (genus: Calocedrus, Chamaecyparis, Cupressus, Juniperus and Thuja), Lauraceae (genus: Laurus) and Taxaceae (genus: Taxus) (García Morale et al., 2016).

The presence of $P$. vovae in Greece is referred by Cox (1989) and Cox and Ben-Dov, (1986). Milonas and Kozár (2008) recorded the scale on Cupressus leylandii (Jacks. and Dallim.) in Kifissia (Attica) in 2004. In Messenia, female adults of $P$. vovae were found on Juniperus oxycedrus L. in June 2006 on Taygetus Mountain (Stathas et al., 2011). The low population of the infestation of the scale found on Taygetus, was not adequate to study the biology of the scale in this area. In Italy P. vovae develops two annual generation (Francardi and Covassi, 1992).

\section{KERMESIDAE}

\section{Kermes echinatus Balachowsky}

Kermes echinatus has been recorded only in Israel and in Greece. Its host plants are the species Quercus calliprinos Webb., Quercus coccifera L. and Quercus ilex L. (Fagaceae) (Spodek et al., 2014; García Morales et al., 2016).

In Greece, K. echinatus was found on $Q$. coccifera in Crete in April 2010 and again in June 2011 (Porcelli and Pellizzari, 2014). In Messenia, it was recorded on Q. ilex in Kalamata, in November 2012 (Fig. 15). In December of the same year, the scale was recorded in Athens on Quercus ilex which was reported as host of this scale for the first time (Stathas et al.,2013; Stathas et al., 2018).

The phenology and the natural enemies of $K$. echinatus on Q. ilex were studied in Kal- amata during the years 2015 - 2017 (Stathas et al., 2018). Kermes echinatus is a univoltine, oviparous and biparental species. It overwintered as first instar nymph on the branches of the infested trees and it was developed to second instar by the middle of April and to third instar until the end of May. The immature males (larvae and pupae) were observed from the end of April until the end of
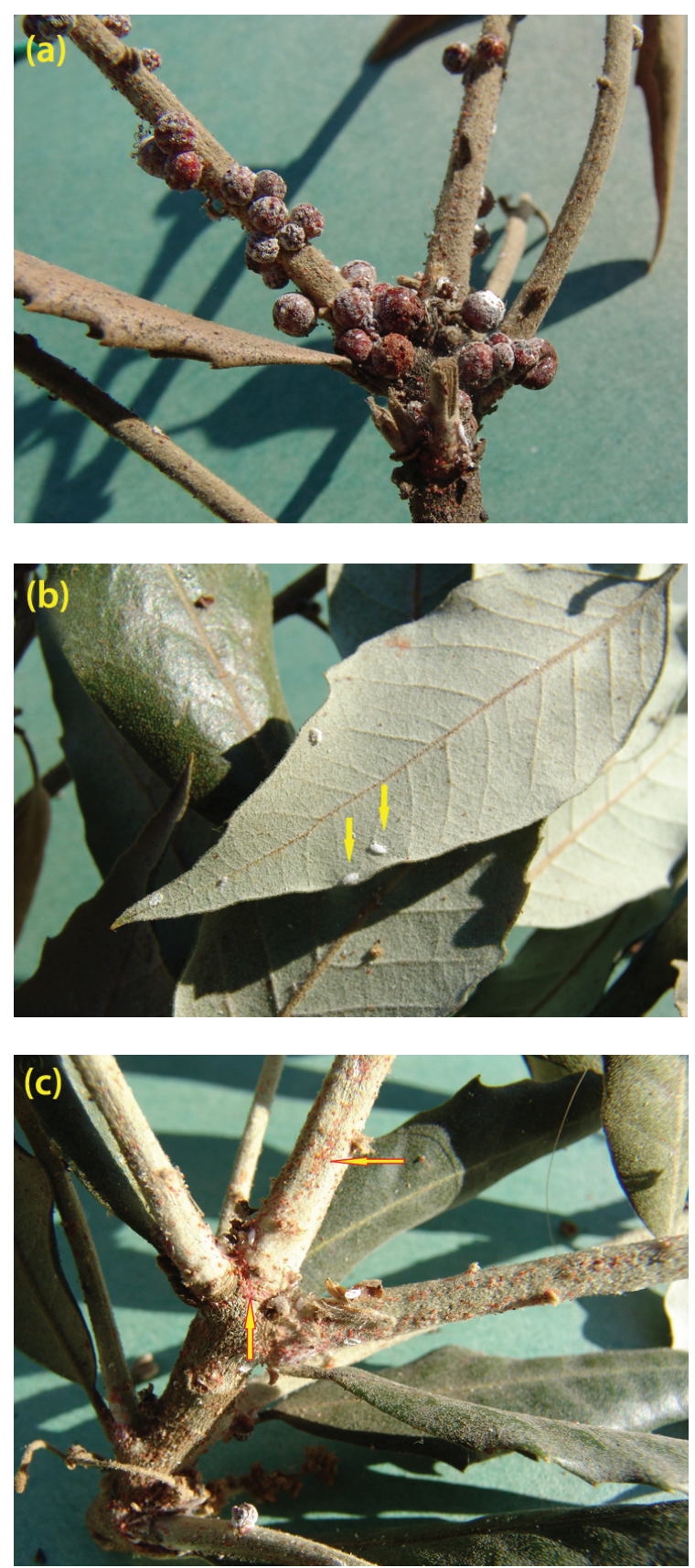

Figure 15. Kermes echinatus on Quercus ilex. (a): oviparous female adults, (b): scale covers of male nymphs, (c): crawlers dispersed on branches in Kalamata, Greece (Photo by George Stathas). 
May, while the pre-ovipositing and ovipositing adults were recorded during May and June. The hatching of crawlers occurred by the end of June, which remained under this instar until the April of the next year. Natural enemies included the predator Chilocorus bipustulatus and the parasitoids Metaphycus gennaroi Guerrieri and Noyes, The hyperparasite Cheiloneurus claviger Thomson (Hymenoptera: Encyrtidae) was also found parasitizing the scale. The total parasitization rate of both parasitoids reached to $21 \%$ (Stathas et al., 2018).

\section{Concluding remarks}

Twenty species of scale insects were recorded on agricultural, ornamental and forest plant species in the wider area of Messenian Province between the years 2000 and 2020. Nine of them belong to the family Diaspididae, eight to Coccidae, two to Pseudococcidae and one to Kermesidae. Some of these scale species or their parasitoids are recorded for the first time in Greece. For some other, this is the first report of several host plant species.

First records of these scale species in Greece include: Physokermes inopinatus on Taygetus mountain; Protopulvinaria pyriformis in Kalamata (Ben-Dov et al., 2003); Kermes echinatus in Messenia (the scale has not been previously recorded in continental Greece, but only in Crete) (Stathas et al., 2013; Porcelli and Pellizzari, 2014).

First records of host plant species include: Physokermes inopinatus was recorded on A. cephalonica (Stathas and Kozár, 2010); Kermes echinatus was recorded on Quercus ilex; the scale was previously recorded only on Q. calliprinos and Q. coccifera (Stathas et al., 2013). Chrysomphalus aonidum was recorded for the first-time infesting species of the families Cucurbitaceae and Solanaceae (mass reared on C. maxima and S. tuberosum) and the plant $F$. bensamina (Stathas et al., 2002; Stathas and Kozár, 2008). Infestation by $P$. madeirensis was recorded on Osteospermum jucundum (Stathas et al., 2015b).
First reports of parasitoids of the scale species include: Aphytis debachi found on D. echinocacti is the first record of this ectoparasistoid in Europe; Plagiomerus diaspidilis in Kalamata is the first report of this ectoparasitoid in Greece (Japoshvili et al., 2010).

The data on biology, phenology and ecology of the scale insects provided in this article, could contribute to their effective control. The knowledge of the time of appearance of the most susceptible stages of the scale to chemicals, the number of generations developed per year, their fecundity and the evaluation of the action of their natural enemies, is necessary and essential when planning an effective program of their Integrated Pest Management.

The first author expresses his gratitude to $\mathrm{Dr}$ Panayiotis Katsoyannos, Research Director of National Agricultural Research Foundation (NAGREF), Head of the Laboratory of Biological Control of the Benaki Phytopathological Institute until 1997, for his guidance and instruction on scale insects and on their natural enemies.

\section{Literature cited}

Argyriou, L.C., Sravraki, H.G. and Mourikis, P.A. 1976. A list of Recorded Entomophagous Insects of Greece. Benaki Phytopathological Institute, Athens, Greece, 73pp.

Argyriou, L.C. 1983. Faunal analysis of some scale insects in Greece. Proceedings of the $10^{\text {th }}$ International Symposium of Central European Entomofaunistics, Budapest, 15-20 August 1983 364367.

Argyriou, L.C., and Santorini, A.P. 1980. On the phenology of Ceroplastes rusci L. (Hom. Coccidae) on fig-trees in Greece. Mededlingen van de Rijksfaculteit Landbouwwetenschappen te Gent, 45: 593-601.

Argyriou, L.C. and Mourikis, P.A., 1981. Current status of citrus pests in Greece. Proceedings of the International Society of Citriculture, Tokyo 9-12 November, International Society of Citriculture, Okitsu, Japan, Vol. 2: 623-627.

Balachowsky, A.S. 1954. Les cochenilles Paléarctiques de la tribu des Diaspidini. Memmoires Scientifiques de I'Institut Pasteur. Paris; Institut Pasteur Publ. 
Belguendouz, R., Biche, M., and Bendifallah, L. 2017 Study of Trophic Relationships Between Diaspididae Family Species - Host Plants - Predators and Parasitoids in Algeria. Journal of Fundamental and Applied Sciences, 9(1): 119-135.

Ben-Dov, Y., Stathas, G.J. and Malliarou, J.S. 2003. The pyriform scale, Protopulvinaria pyriformis (Cockerell) (Hemiptera: Coccidae) in Greece. Agrotiki Erevna, 26(2): 89-91.

Cox, J.M. 1989. The mealybug genus Planococcus (Homoptera: Pseudococcidae). Bulletin British Museum (Natural History). Entomology, 58(1): 1-78.

Cox, J.M., and Ben-Dov, Y. 1986. Planococcine mealybugs of economic importance from the Mediterranean Basin and their distinction from a new African genus (Hemiptera: Pseudococcidae). Bulletin of Entomological Research, 76: 481-489.

DeBach, P. 1964. Some species of Aphytis Howard (Hymenoptera: Aphelinidae) in Greece. Annales de I'Institut Phytopathologique Benaki, 7(1): 5-18.

Francardi, V. and Covassi, M.V. 1992. Note bio-ecologiche sul Planococcus vovae (Nasonov) dannoso a Juniperus spp. in Toscana (Homoptera Pseudococcidae). [Biological and ecological notes on Planococcus vovae (Nasonov) (Homoptera Pseudococcidae living on Juniperus spp. in Tuscany. Redia, 75: 1-20.

Garcia Mari, F., Soto, A., Hernandez Penadès, P., Rodrigo, E. and Rodriguez Reina, J.M. 2000. Una nueva cochinilla aperece en los cítricos valencianos, Chrysomphalus aonidum. Phytoma Espaňa, 117: 35-40.

García Morales, M., Denno, B.D., Miller, D.R., Miller, G.L., Ben-Dov, Y. and Hardy, N.B. 2016. ScaleNet: A literature-based model of scale insect biology and systematics. Database. doi: 10.1093/database/bav118. http://scalenet.info. (Accessed: 4/1/2021).

Germain, J.F. and Matile Ferrero, D. 2005. Les co-chenilles sous serres en France : inventaire illu-stré. III - Les Diaspididae. Phytoma, 583: 32-35.

Google map 1: https://www.google.gr/maps/place/ Messenia/@37.0837231,21.9086108,10z/data=! $4 \mathrm{~m} 5$ !3m4! $1 \mathrm{~s} 0 \times 136102 \mathrm{~cd} 91712287: 0 \times 110575 \mathrm{be} 2$ $5 \mathrm{~d} 07 f 19 ! 8 \mathrm{~m} 2$ ! 3d37.1424653!4d21.9522491 (accessed on 18/05/2021).

Google map 2: https://www.google.gr/ maps/@38. 2349212,22.0384587,7z (accessed on 18/05/2021).

Gordh, G. and Lacey, L. 1976. Biological studies of Plagiomerus diaspis Crawford, a primary internal parasite of diaspidid scale insects $(\mathrm{Hy}$ menoptera: Encyrtidae; Homoptera: Diaspididae). Proceedings of the Entomological Society of Washington, 78: 132-144.

Gounari, S., Mathiopoulos, M., Stathas, G.J. and Emmanouel, N. 2004. Aspects on bioecology and phenology of Physokermes hemicryphus (Dalman) in the county of Euritania - Greece. In Proccedings of the X-International Symposium on
Scale Insect Studies (ISSIS-X). 19-23 April, Adana, Turkey, 339p.

Hadzibejli, Z.K. 1967. Ecological characteristics of the genus Eulecanium Ckll. in the fauna of Gruzia. Trudy Instituta Zashchita Rastenii Gruzinskoy SSR 19: 59-63.

Hall, W.J. 1922. Observations on the Coccidae of Egypt. Bulletin, Ministry of Agriculture, Egypt, Technical and Scientific Service, 22: 1-54.

Herting, B. and Simmonds, F.J. 1972. A catalogue of parasites and predators of terrestrial arthropods. Farnham Roy., U.K. 210 pp.

Jansen. M.G.M. 2004. An updated list of scale insects (Hemiptera: Coccoidea) from importinterceptions and greenhouses in The Netherlands. Proc. X International Symposium on Scale insects studies, Adana, Turkey, 147-165 pp.

Japoshvili, G.O., Stathas, G.J. and Kampouris, S.G. 2010. Natural enemies of Diaspis echinocacti in Greece and first records of Aphytis debachi and Plagiomerus diaspidis. Phytoparasitica, 38: 121-123.

Katsoyannos, P., 1976. Etude d' un predatéur: Exochomus quadripustulatus I. (Col.: Coccinellidae) en vue d' un éventuelle utilization contre Saissetia oleae Olivier (Ho.: Coccoidea-Coccidae) dans les oliveraies de la Grèce. Doct. Ing. Thesis Acad. Montpellier, Univ. Sci. et Techn. Du Langueloc, France, 144 pp.

Katsoyannos, P. 1993. Phenology and natural enemies of Lineaspis striata Newstead (Homoptera: Diaspididae) in Attica. Proceedings of the $5^{\text {th }}$ PanHellenic Congress of Entomology. 8-10 November, Athens, Greece, 201-205.

Katsoyannos, P. 1996. Integrated Insect Pest Management for Citrus in Northern Mediterranean countries. Benaki Phytopathologica IInstitute, Athens, Greece, 110 pp.

Koroneos, J. 1934. Les Coccidae de la Grèce sur tout du Pélion (Thessalie). I. Diaspinae. Athens. 95p.

Kosztarab, M.P. and Kozár, F., 1988. Scale Insects of Central Europe. Akademiai Kiado Budapest, Hungary $456 \mathrm{pp}$.

Kozár, F. 1985. New data to the knowledge of scaleinsects of Bulgaria, Greece, and Rumania (Homoptera: Coccoidea). Acta Phytopathologica Academiae Scientiarum Hungaricae, 20: 201-205.

Kozár, F., Paloukis, S. and Papadopoulos, N. 1991. New Scale Insects (Homoptera: Coccoidea) in the Greek Entomofauna. Entomologia Hellenica, 9: 63-68.

Kozstarab, M. and F. Kozár. 1988. Scale insects of central Europe. Akademiai Kiadó, Budapest, 456pp.

Kyparissoudas, D.S. 1992. Flight of White Peach Scale, Pseudaulacaspis pentagona, males and time of crawler appearance in Northern Greece. Entomologia Hellenica, 10: 21-24.

Milonas, P.G. and Kozár, F. 2008. Check list of mealybugs (Homoptera: Pseudococcidae) in Greece: 
three new records. Hellenic Plant Protection Journal, 1(1): 35-38.

Paloukis, S.S. 1967. Prospaltella berlesei How. (Hymenoptera-Aphelinidae), an entomoparasite specifique of Pseudaulacaspis pentagona Targ. (Coccidae), pest of peaches trees in Macedonia. Geoponica, 159-161.

Paloukis S.S. and Mentzelos I. 1971. Contribution a l'étude de la bio-écologie et de la lutte de Pseudaulacaspis (Diaspis) pentagona Targ. (Homoptera: Diaspididae) ennemi du pêcher en Macedoine Centrale (Grèece). Stationde Rècherche pour la Protection des Plantes, Thessalonique, Grèece, Bull. I.

Paloukis, S.S. 1979. The main scale insects of fruit trees in Northern Greece. [in Greek]. Thessaloniki, 148p.

Panis, A., 1981. Les cochenilles circum-Méditerranéennes des arbres d'alignement et brisevent (Homoptera, Coccoidea). Sixièmes Journées Phytiatrie and Phytopharmacie Circum-Mediterranéennes, 1-11.

Panis, A. and Pinet, C. 1999. A study of two Plagiomerus species (Hymenoptera: Encyrtidae) parasitising diaspidid scales (Coccoidea) in glasshouses in France. Entomologica, 33: 423-427.

Papadopoulou, S. and Chryssohoides, C. 2012. Phenacoccus madeirensis Green, 1923 (Homoptera: Pseudococcidae) on Ocimum basilicum: a new geographical record for Greece. EPPO Bulletin, 42(1): 146-147.

Pellizzari, G. and Vacante, V. 2007. Una nuova cocciniglia sulgi agrumi in Italia: il Chrysomphalus aonidum (Linnaeus) (Hemiptera: Diaspididae). Informatore Phytopathologico, 45-47.

Pellizzari, G., Rainato A. and Stathas, G.J. 2010. Description of the immature female instars of Ceroplastes rusci (Linnaeus) (Hemiptera: Coccidae). Zootaxa, 2556: 40-50.

Pellizzari, G., Porcelli, F., Seljak, G. and Kozár, F. 2011. Some additions to the Scale insect fauna (Hemiptera: Coccoidea) of Crete with a check list of the species known from the island. Journal of Entomological and Acarological Research Ser. II, 43(3): 291-300.

Porcelli, F. and Pellizzari, G. 2014. Description of female nymphal instars and adult female of Kermes echinatus Balachowsky (Hemiptera, Coccoidea, Kermesidae) based on specimens from Crete and mainland Greece, with a discussion on geographical variation. Zootaxa, 3878(1): 061-074.

Rakimov, A., Ben-Dov, Y., White, V., and Hoffmann, A.A. 2013. Soft scale insects (Hemiptera: Coccoidea: Coccidae) on grapevines in Australia. Australian Journal of Entomology 52: 371-378.

Reiderne, S.K. and Kozár, F. 1994. Recently appeared scale insect species (Homoptera, Coccoidea, Diaspididae) on glasshouse ornamentals in Hungary. Novenyvedelem, 30: 423-427.
Rosen, D. and DeBach, P. 1979. Species of Aphytis of the world (Hymenoptera: Aphelinidae). The Hague, the Netherlands: Dr. W. Junk BV -Publishers.

Santas, L.A. 1983. Insects producing honeydew exploited by bees in Greece. Apidologie 14: 93-103.

Santas, L.A. 1985. Parthenolecanium corni (Bouché) an orchard scale pest producing honeydew foraged by bees in Greece. Entomologia Hellenica, 3: 53-58.

Santas, L.A. 1988. Physokermes hemicryphus (Dalman) a fir scale insect useful to apiculture in Greece. Entomologia Hellenica, 6: 11-22.

Sinacori, A. 1995. Bio-ethological observations on Phenacoccus madeirensis Green (Coccoidea: Pseudococcidae) in Sicily. Israel Journal of Entomology, 29: 179-182.

Spodek, M., Ben-Dov, Y. and Mendel, Z. 2014. The scale insects (Hemiptera: Coccoidea) of oak trees (Fagaceae: Quercus spp.) in Israel. Israel Journal of Entomology, 43: 95-124

Stathas, G.J. 1997. First record of Nemolecanium graniformis Wünn) (Homoptera: Coccidae) in Greece. Annales de I'Institut Phytopathologique Benaki, 18: 57-59.

Stathas, G.J. 2001. The scale Nemolecanium graniformis (Wünn) (Homoptera: Coccidae) in Greece. Anzeiger für Schädlingskunde (Journal of Pest Science), 74: 57-59.

Stathas, G.J. and Kontodimas, D.C. 2001. Ecological data of the scale Targionia vitis on grapes in Southern Greece. Annalsdel'Institut Phytopathologique Benaki,19: 134-139.

Stathas, G.J., Eliopoulos, P.A., Kontodimas, D.C. and Siamos D.Th. 2002. Adult morphology and life cycle under constant temperatures of the predator Rhyzobius lophanthae Blaisdell (Col., Coccinellidae). Anzeiger für Schädlingskunde (Journal of Pest Science), 75: 105-109.

Stathas, G.J., Eliopoulos, P.A., Bouras, S.L., Economou, L.P. and Kontodimas, D.C. 2003. The scale Parthenolecanium persicae (Fabricius) on grapes in Greece. IOBC/WPRS Bulletin, 26(8): 253-257.

Stathas, G.J. 2004a. Ecological data of Lepidosaphes gloverii (Hemiptera: Diaspididae) in Greece. Entomologia Hellenica, 15: 19-26.

Stathas, G.J. 2004b. First record of the scale Parthenolecanium persicae on Viburnum tinus and Vitis vinifera in Greece. Annals of the Benaki Phytopathological Institute, 20(1): 57-59.

Stathas, G.J., Eliopoulos, P.A., Porichi, E.E., Katsanis, A.G. and Beratis, V.N. 2005. The scale insect Aonidiella aurantii (Maskell) (Hemiptera: Diaspididae) on orange trees in Messenia. Abstracts of 11th Panhellenic Entomological Congress, Karditsa, October 11-14, p 9.

Stathas, G.J. 2008. The scale insect Dynaspidiotus abietis (Schrank) on Abies cephalonica (Pinace- 
ae). Entomologia Hellenica, 17: 28-33.

Stathas, G.J. and Kozár, F. 2008. Chrysomphalus aonidum as a pest of citrus in Greece. Entomologia Hellenica, 16 (2005-2006): 16-21.

Stathas, G.J., Kartsonas, E.D. and Kontodimas D.C., 2008. New hosts for the pyriform scale Protopulvinaria pyriformis (Cockerell) (Hemiptera: Coccidae) in Greece. Entomologia Hellenica, 17 (2007-2008): 56-59.

Stathas, G.J., Eliopoulos, P.A., Japoshvili, G.O. and Kontodimas, D.C. 2009. Phenological and ecological aspects of Protopulvinaria pyriformis (Cockerell) (Hemiptera: Coccidae) in Greece. Journal of Pest Science, 82: 33-39.

Stathas, G.J. and Kozár, F. 2010. First record of Physokermes inopinatus Danzig \& Kozár 1973 (Hemiptera: Coccidae) in Greece. Hellenic Plant Protection Journal, 3: 7-8

Stathas, G.J., Eliopoulos, P.A., Salmas, I.C. and Kozár, F. 2011. Data on ecology of some Hemiptera species recorded in the forest of Taygetus Mountain, Peloponnesus, Greece. Phytoparasitica, 39: 377-383.

Stathas, G.J., Kartsonas, E.D. and Skouras, P.J. 2013. First record of Kermes echinatus Balachowsky (Hemiptera, Coccoidea, Kermesidae) on Quercus ilex. Entomologia Hellenica, 22(1): 19-22.

Stathas, G.J. 2015. The scale insect Dynaspidiotus abieticola (Koroneos) (Hemiptera: Diaspididae) on the Taygetus mountain in Greece. Hellenic Plant Protection Journal, 8: 63-65.

Stathas, G.J., Skouras, P.J. and Kontodimas, D.C. 2015a. Data on ecology of the purple scale Lepidosaphes beckii (Newman) on citrus in Greece. Bulletin OEPP/EPPO, 45(1): 128-132.
Stathas, G.J., Kartsonas, E.D. and Darras, A.I. 2015b. Record of Phenacoccus peruvianus Granara de Willing and Phenacoccus madeirensis (Hemiptera: Pseudococcidae) on new host ornamental plants in Greece. Hellenic Plant Protection Journal, 8: 12-14.

Stathas, G.J., Kartsonas, E.D., Skouras, P.J. and Darras, A.I. 2018. Data on the ecology of Kermes echinatus Balachowsky (Hemiptera, Coccomorpha, Kermesidae) on Quercus ilex (Fagaceae) in Greece. Phytoparasitica, (46): 491-498.

Stathas, G.J., Kostriva, A., Skouras, P.J., Kontodimas, D.C. and Karipidis, C.F. 2020. Data on biology and ecology of Pseudaulacaspis pentagona (Targioni Tozzetti) (Hemiptera: Diaspididae) on fruit trees in the Peloponnese. Journal of Agronomy and Animal Industries, 15 (2): 142-149.

Szita, É., Fetykó, K., Konczné Benedicty, Z., Kozár, F., Partsinevelos, G.K., Milonas, P.G. and Kaydan, M.B. 2017. Data on the scale insect (Hemiptera: Coccomorpha) fauna of Greece, with description of two new species. Zootaxa 4329(5): 463476.

Received: 17 February 2021; Accepted: 23 May 2021

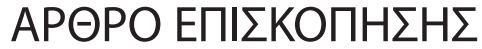

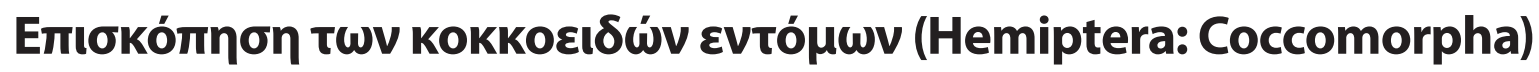

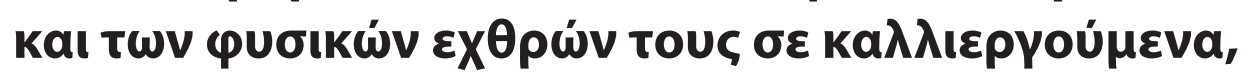

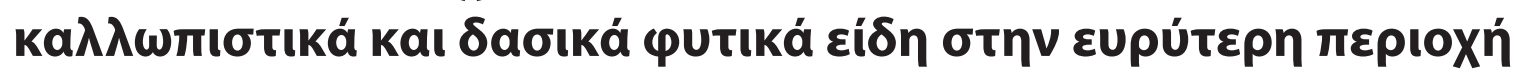

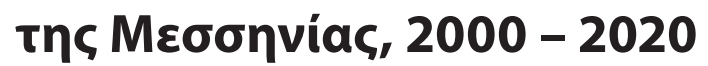

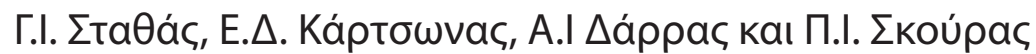

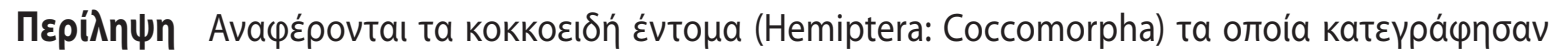

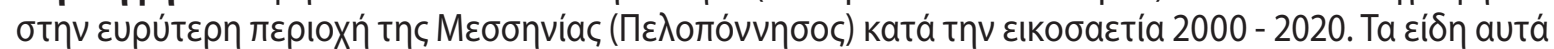

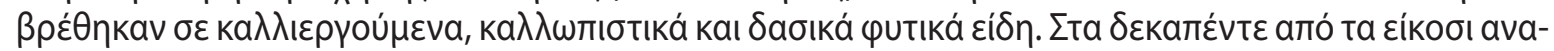

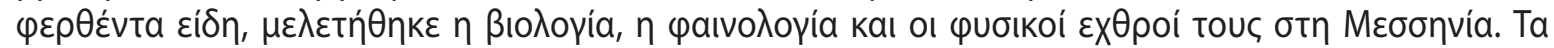

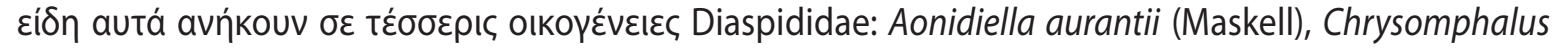
aonidum (L.), Diaspis echinocacti (Bouché), Dynaspidiotus abieticola (Koroneos), D. abietis (Schrank), Lepidosaphes beckii (Newman), L. gloverii (Packard), Lineaspis striata (Newstead), Targionia vitis 
(Signoret), Coccidae: Ceroplastes rusci (L.), Eulecanium sericeum (Lindinger), Nemolecanium graniformis (Wünn), Parthenolecanium corni (Bouché), P. persicae (Fabricius), Physokermes hemicryphus (Dalman), P. inopinatus Danzig and Kozár, Protopulvinaria pyriformis (Cockerell), Pseudococcidae: Phenacoccus madeirensis Green, Planococcus vovae (Nasonov) kaı Kermesidae: Kermes echinatus Balachowsky.

Hellenic Plant Protection Journal 14: 47-64, 2021 